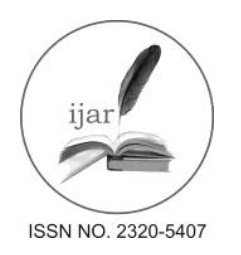

\author{
Journal homepage: http://www.journalijar.com

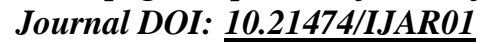

INTERNATIONAL JOURNAL

OF ADVANCED RESEARCH

RESEARCH ARTICLE

\title{
THE CHASM BETWEEN EXPECTED AND REAL PERFORMANCES OF ROMANIA- A PATH DEPENDENCE OUTCOME.
}

\author{
*Oana-Ramona Socoliuc ${ }^{1}$, Ion Pohoață ${ }^{2}$ and Delia-Elena Diaconaşu ${ }^{3}$. \\ 1. Assistant Professor Ph.D., Faculty of Economics and Business Administration, Alexandru Ioan Cuza University \\ of Iaşi, Romania. \\ 2. Professor Ph.D., Faculty of Economics and Business Administration, Alexandru Ioan Cuza University of Iaşi, \\ Romania. \\ 3. Research Scientist III, Faculty of Economics and Business Administration, Alexandru Ioan Cuza University of \\ Iaşi, Romania.
}

\section{Manuscript Info}

Manuscript History:

Received: 22 May 2016

Final Accepted: 19 June 2016

Published Online: July 2016

Key words:

Path dependence, Institutional effectiveness,

European integration.

*Corresponding Author

Oana-Ramona Socoliuc.

\begin{abstract}
After more than eight years of European Union membership and twenty five years of capitalism, Romania remains bounded at an unsatisfactory and worrying level of economic development. In such a context, some innate questions emerge: is the soviet past a reason for the poor economic performances, and if so, how was possible for other ex-soviet nations to overcome this obstacle and to acquire development under European guidance, but not for Romania? Why, here, the European "vaccine" was not able to generate positive outcomes? The purpose of this paper is to provide a pertinent answer to these questions using the institutionalist theory of path dependence. In order to pursue our endeavour of validating the nexus between the quality of formal and informal institutions and economic evolution, we employ econometric analyses such as Granger causality and Vector Error Correction Model, using time series data ranging from 1995 to 2014 on quality institutional and economic development indicators for Romania. As results point out, unlike other CEE nations, Romania continued all these years under a low institutional effectiveness, by prevailing corruption, bureaucracy, changeable and inefficient laws, aspect that has had a long term influence on its economic development results.
\end{abstract}

Copy Right, IJAR, 2013,. All rights reserved.

\section{Introduction:-}

The collapse of the Soviet Union illustrated a challenging moment for its satellite countries, but also a moment of great hope and enthusiasm with respect to the future, one who had to be projected on democracy, as a metainstitution, and the capitalist values of private property, freedom, individualism, competition and efficiency. The greatest challenge so far, for all these nations was the construction of the new institutional arrangements capable to enhance, create the necessary incentives, and support a major transformation like this (Pejovich, 2006; Rodrik, 2000). In order to materialize the transition from a centrally planned to a market oriented economic system some countries like the Czech Republic, Poland, Hungary, Estonia, Lithuania, the Slovak Republic have applied the shock therapy, while others, such as Romania, Bulgaria, Croatia, Ukraine, etc., have opted for the less social painful version, the gradual metamorphosis (Wolf, 1999). Detached from the body of the Soviet Union, these nations have followed different economic trajectories which strongly depended on their national specific in terms of formal and informal institutional background, mainly culture, but furthermore, on the will of those who had the power to initiate and implement the transition process (North, 1990; Giannaros, 2007; Pejovich, 2006). From a general perspective, the vast majority of these countries have, apparently, a common soviet experience coming from the past and moreover, also, a current European Union membership status, but despite this, there are significant disparities in 
terms of transition preconditions which generated a kind of spillover effect in terms of economic dynamics that is responsible for the existing present disparities under the EU tutelage (Giannaros, 2007; Pohoaţă et al., 2013).

On the basis of the path dependence theory, the paper aims to provide an applied analysis to the particular case of Romania's unsatisfactory level of development, whose reasons are deeply rooted in the ineffective informal institutions, reflected afterwards in the inefficient formal rules that guided Romanian society after 1990s. Using the existing body of literature in the field and also econometric analyses, such as a Granger causality and a Vector Error Correction Model applied to institutional and economic development indicators, we intend to point out that national conditions, which preceded the transition process, are responsible not only for the malfunctioning of the market economy in Romania, but also for the present development gaps between Romania and the other countries from Central and Eastern European area, despite their common membership to the EU. Furthermore, in order to accentuate the extremely low performances registered by Romania after so many years spent under democracy, capitalism, but mainly, under European governance, we use the comparative approach with the high performance countries from Central and Eastern European region.

\section{Research objectives:-}

1. To provide a clear image of the conditions that preceded the transition process in Central and Eastern European countries with particular focus on Romania, in order to highlight the different manner in which these nations have assimilated soviet values, beliefs and attitudes, vitiating thus further development potential.

2. To emphasise the major differences in terms of institutional quality between these nations at the beginning of the transition process and how they became increasingly more pronounced under capitalism.

3. To demonstrate theoretically and empirically that precisely the quality of the rules of the game inherited from the past is responsible for the formal integration of Romania within EU.

4. To propose a set of measures in order to increase, on the medium and long run, the quality of institutions in Romania, so necessary for determining an incremental changing process.

The motivation of the paper resides, first, in the limited number of researches applied to the particular case of Romania, but especially the worrying situation to which the country is confronted with and the imperious need to determine a profound social and economic transformation. Second, by considering the present global challenges that require a united European Union from all points of view: social, economic, political, there is a critical need for a concerted action of the 28 member states in order to overcome the refugee crisis, the euro zone problems, etc. Because not all members are equally efficient in applying EU norms and the existing lags in terms of economic development and institutional effectiveness are deepening, EU is becoming more vulnerable in front of external shocks.

The novelty of our analysis is deriving from at least two aspects. First, the use of the theoretical concepts and the specific terms of the New Institutional Economics, namely the path dependence phenomenon, will allow us to intercept the fundamental contribution of the informal institutions on what is happening on the formal register and, consequently, its repercussion on the socio-economic life. Second, the originality of the paper is deriving from the approach to be used, consisting in a mix between the theoretical and empirical analysis.

\section{Literature review:-}

The performances of transition economies from Central and Eastern Europe illustrated a topic which captured the attention of many scholars but also experts of international organizations, such as: the World Bank, the European Bank for Reconstruction and Development, the International Monetary Fund, etc. It regained popularity when a part of the ex-soviet countries joined European Union in 2004, the moment of the biggest enlargement, when the Czech Republic, Poland, Hungary, Estonia, Latvia, Lithuania, the Slovak Republic, and Slovenia and then in 2007, Romania and Bulgaria became fully members. Considering the different moments of accession, there were undoubtedly significant discrepancies in terms of institutional arrangements on which these societies were based, but also in terms of progresses made in order to build a functional market economy.

Institutions or the rules of the game, as North (1990) pointed out, illustrate the fundamental component of any society, they provide the arrangements which guide human interaction, generate order, reduce uncertainty and, furthermore, determine predictive behaviours among individuals, boosting human cooperation. Depending on the provenience and quality (good or bad) of such institutions, they predict and induce the path toward economic evolution or, on the contrary, economic involution of the respective society. According to Veblen, the evolution of 
institutions means precisely the evolution of society itself (Veblen, 1994). Consequently, being the result of a process occurred in the past, adapted to the past circumstances, institutions are able to explain the economic progress or, on the contrary, the poor economic performances of the nations. Through formal institutions we understand economic, social, political rules created and designed by human mind in order to facilitate order, cooperation and to reduce uncertainty (North, 1990). By informal rules or norms we understand cultural heritage, values, beliefs, customs, traditions, attitudes, codes of conduct, norms of behaviour transmitted from a generation to another through teaching and imitation (North, 1990; Boyd and Richerson, 1985). The mix between the formal and, mainly, the informal institutional component is fundamental in guiding nations towards wealth and prosperity, or, on the contrary, towards underdevelopment. As Douglass North highlighted, those countries that were guided by good institutions in the past, meaning a positive informal background, healthy rule of law, clear property rights and effective economic principles had the advantage of a solid basis for acquiring growth and development (North, 2005). Conversely, countries that were dominated by corruption, bureaucracy, low enforceability of rules and laws, opportunism, political clientelism are not benefiting from the necessary background in order to acquire good formal rules and, moreover, wealth. Romania is definitely placed in the latter category of nations, where the rules of game were not effective, illustrating, thus, an obstacle for the economic progress.

The institutional dynamics is favourable to economic development when the changing process that occurs on the formal institutional area is supported by the informal values, beliefs, attitudes, codes of conduct. The new institutional mix based on a positive interaction will allow and facilitate economic growth, especially when the new implemented norms are protecting freedom of individuals, intensifying the division of labour, competition and economic effectiveness (Kasper and Streit, 1998). On the contrary, when formal institutions (laws, regulations, etc.) are changing but the new created ones are not on the same wavelength with the informal background of the respective nation, even though they may be effectively projected, once applied they fail to create the expected positive outcomes. Such negative interaction will increase transaction costs and, thus, economic development potential will be, undoubtedly, reduced (Pejovich, 1999). This is precisely the situation of Romania as a European Union member.

Such aspects were pointed out earlier, before 2004 in the reports of World Bank on transition issues, and also in many other research papers. According to Mila Kunder (1997) and Beatrice Weder (2001), countries such as Poland, Hungary, the Baltic States or the Czech Republic have benefited from a better institutional background, so they were considered as having a strong affinity for wealth and development. Starting with 1968, Hungary hosted the first initiatives of decentralisation, providing measures which encouraged the private sector (Florescu-Ciobotaru, 2009). Even though they were faded at that moment, they had a positive impact on the inland social psychology, modelling it on a liberal shape. In Poland, the same wave of reforms was designed in 1980s, being oriented on the same direction of autonomy, consisting in both the liberalisation of production activities, and international trade, and financing the investment projects. In fact, in Poland, the agricultural sector was never collectivised (Giannaros, 2007). Also, starting from 1987, the little entrepreneurs were advantaged by the reforms undertaken in order to strengthen the private sector and to materialise the detachment from socialism (Florescu-Ciobotaru, 2009). Consequently, we observe that these nations manifested an intense affinity towards values of capitalist economy, a sign that their informal institutional background was not that strongly affected by the communist regime. In other words, their capacity to resist in front of the communist ideology was stronger than in the case of Romania or Bulgaria.

On the opposite, Romania was included together with Bulgaria in the second cluster of countries, the one that were power oriented. Here, the persistence of the past values that marked a sort of cultural handicap restricted development at an unsatisfactory level. Today corruption remained one of the greatest problems to which Romania is confronted with, despite its EU membership. It is present not only in the private sector, but mainly in the public sector, where bribe and the power abuse are most frequently encountered. Aspects such as political democratisation, a higher level of administrative centralisation (Alt and Lassen, 2003), the lack of transparency of the public expenditures, the instability of governmental policies, poor quality of the rule of law, as well as economic fragility, social inequalities, or the privatization of public resources (Richter and Burke, 2007), poverty, even religion (Treisman, 2000) illustrate sources of corruption. This is a kind of legacy of the soviet regime which Bulgaria, but mainly Romania, embraced and perpetuated it through political elites, political clientelism, higher bureaucracy and lower transparency promoted within public institutions, being similar, in a certain extent, to the model continued by Russia after 1990s (Libman and Obydenkova, 2013). 
For the particular case of Romania, before 1989 there were no initiatives designed to support private property and freedom of individuals. Here, Ceausescu's regime with its intense personality cult was one of the most coercive from the entire region. Romanians were obedient and assimilated so profoundly the ideology of socialism that it negatively modelled the values, beliefs and their own mentality. Practically, the step by step transition provided a fertile ground for policymakers to persist in the same bureaucracy, opportunism, corruption, the poor quality of the rule of law and its inconsistency, in other words, institutional ineffectiveness. Romania hosted a long, reluctant and immoral transition to the market oriented economy, with imprecise goals (Pohoaţă, 2000). In such context, it was obvious that the "opportunity window" of EU membership could not be fully exploited in order to strengthen institutions, to generate growth and economic development as it was expected (Balcerowicz, 1993). The past is showing us that each ex-soviet country captured and assimilated socialist values, beliefs, codes of conduct or norms of behaviour in different extent. This was possible because back in history, each country had its own path, and inherited a different artefactual structure, values and cultural insights which made them more vulnerable to centralization and coercion or, on the contrary, stronger enough, as to filter or furthermore, reject them. These distinct heritages with which countries have started the transition process from a centrally planned to a market oriented economic system illustrate the informal institutional background. Such background might be perceived as a sort of dominant gene or the DNA in terms of social transformation.

\section{Material and Methods:-}

Given the fact that State Fragility Index is a performance indicator of governmental policies and consequently reflects the effectiveness of formal rules designed to materialize transition, we employed a Cointegration analysis and Vector Error Correction Model (VECM) on the particular case of Romania, using as variables GDP per capita provided by Eurostat and State Fragility Index provided by Centre for Systemic Peace, Polity IV Report. The latter index has values from 0 (no fragility) to 25 (maximum fragility) and is illustrative mainly for transition economies all over the world, and also for the rest of the nations which have not experienced centralisation in the past. The selected time-span is 1995-2014, given the limited availability of the data. As theoretic framework requires, the variables must be integrated in the same order and does not have to be stationary in level. Vector Error Correction Model automatically transforms data series into the first difference, and at this point, series have to be stationary, in order to perform the analysis. We wanted to see if there is a long run relationship between this indicator that captures the effectiveness of the rules of the game (perceived as institutional theory calls formal institutions) and the unsatisfactory level of economic development.

Second, in order to demonstrate that the quality of informal institutions does affect the level of national fragility, we employed a Granger causality test between State Fragility Index and Corruption Perception Index for Romania, using the same time span 1995-2014. As indicator reflecting the ineffectiveness of informal institutional background, but mainly the legacy of the ex-soviet regime, we have selected Corruption Perception Index provided by Transparency International. A 0 value of the index indicates maximum corruption, while a 100 value points out the lack of corruption. Such index is as an accurate indicator of the communist legacy as is shown in the literature in the field (Aidt, 2009; Akçay, 2006, Davis and Ruhe, 2003).

\section{Result and Discussion:-}

We will employ a VAR analysis between the following variables: GDP per capita (GDP_CAP) and State Fragility Index (SFI). Firstly, the lag length criteria indicated one lag, according to the AIC and SC criteria. Secondly, the Johansen Cointegration test highlighted that there is a long run relationship between variables, as highlighted in Table 1. The results figured in the Table below shows that we reject the null hypothesis of no cointegration and, therefore, we found one cointegrating equation based on both the Trace and Maximum Eigen value statistic between the two analysed variables.

Table 1:- Johansen Cointegration Test.

\begin{tabular}{|l|l|l|}
\hline No. of CE $(\mathrm{s})$ & Trace Statistics & Max-Eigen Values \\
\hline None & $0.531218^{* *}$ & 0.531218 \\
& $(0.0557)$ & $(0.2323)$ \\
\hline At most 1 & $0.309916^{*}$ & $0.309916^{*}$ \\
& $(0.0148)$ & $(0.0148)$ \\
\hline
\end{tabular}

Note: $*$ denotes significant at $5 \%, * *$ denotes significant at $10 \%$. 
The results of the estimated VECM $(0,1)$ meaning zero lags in VECM and one cointegration vector are presented in the following equation:

$\mathrm{D}\left(\mathrm{GDP} \_\mathrm{CAP}\right)=-0.574825530942 *\left(\mathrm{GDP} \_\mathrm{CAP}(-1)+1536.16015465 * \mathrm{SFI}(-1)+93.249471294 * @ \mathrm{TREND}(95)\right.$ $16241.4066412)+101.264052288+35.6961816305 * @$ TREND(95)

$\mathrm{D}(\mathrm{SFI})=-0.000302602171752 *($ GDP_CAP(-1) $+1536.16015465 * \operatorname{SFI}(-1)+93.249471294 * @ \mathrm{TREND}(95)-$ 16241.4066412) - $0.333333333333+1.3198936268 \mathrm{e}-16 * @$ TREND(95).

The value of the R-square of 0.264 is acceptable given the fact that we have only two endogenous variables in the system.

Furthermore, in order to highlight the influence of one variable to the other one, we performed the variance decomposition. The results are illustrated in Table 2 below:

Table 2:- Variance decomposition of variables.

\begin{tabular}{|l|l|l|l|}
\hline Variable & Horizon & Own innovation & Other variable innovation \\
\hline GDP_CAP & 1 & 100.0000 & 0.000000 \\
\hline & 2 & 86.61636 & 13.38364 \\
\hline & 3 & 82.05022 & 17.94978 \\
\hline & 4 & 79.58269 & 20.41731 \\
\hline SFI & 1 & 71.86779 & 28.13221 \\
\hline & 2 & 52.30893 & 47.69107 \\
\hline & 3 & 45.13551 & 54.86449 \\
\hline & 4 & 41.28288 & 58.71712 \\
\hline
\end{tabular}

According to variance decomposition, in Romania, the level of GDP per capita, during a four year horizon, is influenced in a proportion of almost $20 \%$ by state fragility innovations. In other words, the effectiveness of formal rules proposed by the government was able to influence GDP per capita up to $20 \%$ in the analysed period. The remaining own innovation in the level of GDP per capita might be explained in the light of other economic, social and political factors. Parenthetically, we considered a four year horizon because after this period the degree of influence from one variable to another is stabilising.

Considering formal institutions as a standalone factor of development, an almost $20 \%$ explanatory force illustrate a good sign. This means that formal rules and practices of a country have the power to enhance economic growth when they are effective. Romania was guided in all these years spent under the ,third way" capitalism by poor quality formal rules. Consequently, the level of economic development remained limited, despite the European Union membership.

Considering the influence manifested by the GDP per capita on the level of country fragility, here we have a stronger influence, of $60 \%$ in a four years horizon. Such results are on the same wavelength with the New Institutionalist theory that pointed out the path dependence of nations. The level of development of a country is reflecting, thus, a good or, on the contrary, a bad informal institutional background. In fact, it is a consequence of the effectiveness and quality of such unofficial register. A poor country is not benefitting from a solid basis in order to stimulate the emergence of good rules, but contrariwise it remains limited and sentenced to underdevelopment. His poverty is determined precisely by the ineffective regulations that are not oriented toward developing human capital, the poor rule of law unable to protect human rights and to generate trust and order within society, high corruption and bureaucracy, ineffective state institutions, etc. Good formal rules derive from civilisation, freedom and democracy. Romania illustrates a representative case in this respect for the Eastern part of the European Union just because here the legacy of communism remained alive even today.

From a statistical perspective the VEC model is well fitted, most of the variables being statistically significant. The residuals variables were also checked with the diagnosis tests, namely: the Portmanteau autocorrelation test, the Breusch-Godfrey Serial Correlation LM Test, which indicated no serial correlation and the heteroskedasticity Test Breusch-Pagan-Godfrey, which showed no heteroskedasticity. Furthermore, the Normality Test pointed out that the residuals are multivariate normal. 
Lastly, the Granger causality tests, employed in order to see if there is a bidirectional or a unidirectional causality relationship between State Fragility Index (SFI) and Corruption Perception Index (CPI), have pointed out that there is only a unidirectional causality coming from corruption to state fragility level. According to the results presented below, in Table 3, the level of corruption from one, two or three years ago is able to influence the present institutional fragility of Romania. So, corruption remains a legacy of socialism very hard to eliminate.

Table 3:- Granger causality tests.

\begin{tabular}{|l|l|c|}
\hline Null Hypothesis: & F-Statistic \\
\hline For Lag $=1$ & & 0.52424 \\
& & $(0.4802)$ \\
\cline { 2 - 3 } & SFI does not Granger Cause CPI & $7.90596^{*}$ \\
& & $(0.0131)$ \\
\hline For Lag $=2$ & CPI does not Granger Cause SFI & 2.30381 \\
& & $(0.1423)$ \\
\cline { 2 - 3 } & SFI does not Granger Cause CPI & $3.64840^{*}$ \\
& & $(0.0478)$ \\
\hline For Lag $=3$ & CPI does not Granger Cause SFI & 1.64065 \\
& & $(0.2481)$ \\
\cline { 2 - 3 } & SFI does not Granger Cause CPI & $3.65119^{*}$ \\
& & $(0.0470)$ \\
\hline
\end{tabular}

Note: $*$ denotes significant at $5 \%$, meaning that we can reject the null hypothesis.

Considering the nexus between corruption and the level of national state fragility, similar findings highlighting the negative impact of corruption were pointed out by the studies of Hussman et al. (2009) and Asongu (2014). Treisman (2000) also identifies the roots of corruption in the level of development of a country, among other factors. Summarizing, the results of our long- and short-term analysis are on the same wavelength with Treisman (2000) findings, in the sense that a lower level of economic development stimulates corruption and, thus, the level of state fragility. Also, Vallings and Torres (2005) explained that a country becomes more fragile when poverty is also accompanied by ineffective and weak state, meaning poor formal institutions and regulations.

\section{Conclusions:-}

For Romania, as an ex-soviet nation, the path of transition and the present period spent under the EU tutelage were strongly affected by the poor quality of formal institutions, but especially informal norms, values, attitudes inherited from the past. As we have already highlighted, corruption remains a major problem that Romania is still facing with after more than two decades of transition and eight years of EU membership, together with bureaucracy, political clientelism, obedience, etc. All these things make Romania to be just formally integrated within the EU body. Romania needs a profound institutional change; this is a must for the future. It has potential in improving its condition, as a European country which aspires to the statute of developed nation, as well as in the cases of the Czech Republic, Poland, Hungary, etc., but such performance is not possible without a common effort of its citizens to internalize the best European practices. Education might be the way to straighten things. Human capital can be modelled in accordance with the core European values; the young generation illustrates the hope in this respect. By changing the mentality of youth, their contribution as citizens will be stronger enough in order to determine the necessary institutional change, because in the process of growth, institutions do matter.

The present paper brings into light other questions that will be exploited within our future research, such as: how can Romania overcome the challenge of structural reforms in order to acquire competitiveness and development on the basis of sound formal institutions?

\section{Acknowledgement:-}

This paper was financially supported through the Internal Research Grant of "Alexandru Ioan Cuza" University of Iaşi, Romania (Grant UAIC - 2015), CIM registration number GI-2015-21. 


\section{References:-}

1. Akçay, S. (2006). Corruption and human development. Cato Journal, 26: 1-29.

2. Alt, J.E., Lassen, D.D. (2003). The political economy of institutions and corruption in American states. Journal of Theoretical Politics, 15: 341-365.

3. Asongu, S.A. (2014). On the Effect of State Fragility on Corruption. 2014 African Governance and Development Institute WP/14/040. Retrieved from http://dx.doi.org/10.2139/ssrn.2599244

4. Balcerowicz, L. (1993). Lessons and Consequences of the Left's Victory in Poland: Interview. Transition Newsletter, World Bank No. 4, October / November.

5. Boyd, R., Richerson, P. J. (1985). Culture and Evolutionary Process. Chicago: University of Chicago Press USA.

6. Davis, J. H., Ruhe, J. A. (2003). Perceptions of country corruption: Antecedents and outcomes. Journal of Business Ethics,43(4): 275-288.

7. Florescu-Ciobotaru, M. (2009). The countries of Central and Eastern European Countries in the context of redefining the East-West relations. Bucharest: University Press, Romania.

8. Giannaros, D. (2008). Twenty Years after the economic restructuring of Eastern Europe: An economic Review. International Business \& Economics Research Journal, 7(11): 35-48.

9. Hussmann, K. and Tisné, M., Mathisen, H.(2009). Integrity in Statebuilding: Anti-corruption with a Statebuilding Lens. Paris: OECD.

10. Kasper, W., Streit, M. E. (1998). Institutional Economics. Cheltenham, Northampton: The Locke Institute, Edward Elgar, UK.

11. Kunder, M. (1997). The tragedy of the Central Europe in Central Europe. Neuroses, Dilemmas, Utopias, Babeti, A. and Ungureanu C. (eds). Iaşi: Polirom Press, Romania.

12. Libman, A., Obydenkova, A. (2013). Communism or communists? Soviet legacies and corruption in transition economies. Economic Letters, 119: 101-103.

13. North, D. (1990). Institutions, Institutional Change and Economic Performance. Cambridge: Cambridge University Press.

14. North, D. (2005). Le processus du développement économique. Paris: Editions d'Organisation.

15. Pejovich, S. (1999).The Effects of the Interaction of Formal and Informal Institutions on Social Stability and Economic Development. Journal of Markets and Morality, 2, Center of Economic Personalism.

16. Pejovich, S. (2006). The uneven results of institutional changes in Central and Eastern Europe: the role of culture. Social Philosophy and Policy 23(1): 231-254.

17. Pohoaţă, I. (2000). Economic routes of capitalism. Polirom Press, Bucharest, Romania.

18. Pohoaţă, I., Socoliuc, O.R., Diaconaşu, D.E. (2013). Institutional Quality - Determinant of Transition Performances in Central and Eastern European Nations. Review of Economics and Business Studies, VI (2): 21-36.

19. Richter, W., Burke, F. (2007). Combating Corruption, Encouraging Ethics: A Practical Guide to Management Ethics. American Society for Public Administration, 2, Rowman \& Littlefield.

20. Rodrik, D. (2000). Institutions for High Quality Growth: What they are and how to Acquire Them. Cambridge: National Bureau of Economic Research, Working Paper 7540.

21. Aidt, T.S. (2009). Corruption, institutions, and economic development. Oxford Review of Economic Policy 25 (2):271-291.

22. Treisman, D. (2000). The causes of corruption: a cross-national study. Journal of Public Economics, 79 (3): 399-457.

23. Vallings, C., Moreno-Torres, M. (2005). Drivers Of Fragility: What Makes States Fragile. PRDE Working Papers 12824, Department for International Development (DFID), United Kingdom.

24. Veblen, T. (1994). Theory of the Leisure Class. New York: Dover Publications Inc, USA.

25. Weder, B. (2001). Institutional Reform in Transition Economies: How far have they come.IMF.

26. Wolf, H.C. (1999). Transition Strategies: Choices and Outcomes. Princeton Studies in International Finance, 85. 